7. Reprod. Fert. (1970) 22, 155-156

\title{
OSMOTIC ADAPTATION OF SEA-URCHIN SPERMATOZOA
}

\author{
H. TIMOURIAN AND G. WATCHMAKER \\ Bio-Medical Division, Lawrence Radiation Laboratory, \\ University of California, Livermore, California 94550
}

(Received 21st November 1969)

Summary. When male sea-urchins (Lytechinus pictus) are kept in hypo-osmotic sea-water, their spermatozoa are inactive in isosmotic sea-water but active in hypo-osmotic sea-water.

Spermatozoa depend on their motility to accomplish their function of fertilization. In the case of sea-urchins and other marine organisms, the ionic composition of sea-water is among the environmental factors that affect motility and longevity (Bishop, 1962). We have started studies of specific ion concentration changes in the sea-water as they affect the motility of sea-urchin spermatozoa.

Differences are reported here in the motility of spermatozoa depending on whether the male sea-urchins had been kept in either hypo-osmotic or isosmotic sea-water. Such differences occur naturally because the salinity of the local sea-water changes during the spring months due to winter rains.

Sea-urchins of the species Lytechinus pictus (Pacific Bio-Marine Co., Venice, Calif.) were kept in artificial sea-water at 12 to $15^{\circ} \mathrm{G}$ in aquaria as described by Tyler \& Tyler (1966). The isosmotic sea-water was made according to their formula and diluted to $75 \%$ with distilled water to make it hypo-osmotic. Spermatozoa and eggs were obtained from the excised gonads.

The motility indices of the spermatozoa were measured using the spectrophotometric technique published previously (Timourian \& Watchmaker, 1970). The method depends on orientating the spermatozoa by making them flow and then measuring their capacity to return to randomness when the orientating force is stopped. Due to the optical anisotropy of spermatozoa (Walton, 1952), their orientation can be followed with a spectrophotometer (Beckman DB) equipped with a flow cell. In each case, $50 \mu \mathrm{l}$ of sperm suspension were diluted by $50 \mathrm{ml}$ of the sea-water and duplicate motility determinations, $2 \mathrm{~min}$ apart, were made for each time period.

Spermatozoa from sea-urchins previously kept in isosmotic sea-water exhibit decreased motility in sea-water of decreasing salinity. When the males are kept in hypo-osmotic sea-water, the spermatozoa become immobile in isosmotic sea-water. The longer the males are kept in hypo-osmotic sea-water, the more dilute is the sea-water required by the spermatozoa for their motility. Table 1 compares the motility indices for spermatozoa from males kept in hypo- 
osmotic sea-water for 6 weeks along with those of spermatozoa from males collected at the same time but kept in the isosmotic sea-water. Spermatozoa from males kept in hypo-osmotic sea-water and then returned to isosmotic seawater are motile in isosmotic sea-water.

No difference was seen between the eggs of females kept in hypo-osmotic and isosmotic sea-water. In all cases, the eggs were capable of being fertilized in all dilutions of sea-water with both kinds of spermatozoa as long as the spermatozoa were motile.

It is known that mammalian spermatozoa have optimum oxygen consumption at an osmotic pressure isosmotic with seminal plasma (Salisbury, 1962). In the case of sea-urchins, the body fluids are more prone to change with respect to the environmental sea-water (Binyon, 1966). The present study provides evidence that the sperm cells are capable of adjusting to the new seminal environment.

\section{TABLE 1}

MOTILITY OF SEA-URGHIN SPERMATOZOA DILUTED INTO SEA-WATER MADE HYPO-OSMOTIC

\begin{tabular}{|c|c|c|c|c|c|c|c|c|c|c|c|c|}
\hline \multirow{4}{*}{$\begin{array}{c}\text { Minutes } \\
\text { after } \\
\text { dilution* }\end{array}$} & \multicolumn{12}{|c|}{ Motility Index } \\
\hline & \multicolumn{12}{|c|}{ Percentage sed-water } \\
\hline & \multicolumn{2}{|c|}{100} & \multicolumn{2}{|c|}{95} & \multicolumn{2}{|c|}{90} & \multicolumn{2}{|c|}{85} & \multicolumn{2}{|c|}{80} & \multicolumn{2}{|c|}{75} \\
\hline & $I$ & $H$ & $I$ & $H$ & $I$ & $H$ & $I$ & $H$ & $I$ & $H$ & $I$ & $H$ \\
\hline $\begin{array}{r}2 \\
30 \\
60 \\
120 \\
180 \\
240 \\
300\end{array}$ & $\begin{array}{r}18 \cdot 2 \\
6 \cdot 2 \\
3 \cdot 4 \\
3 \cdot 3 \\
4 \cdot 5 \\
3 \cdot 3 \\
1 \cdot 0\end{array}$ & $\begin{array}{l}0 \\
0 \\
0 \\
0 \\
0 \\
0 \\
0\end{array}$ & $\begin{array}{l}0 \\
4 \cdot 4 \\
5 \cdot 1 \\
4 \cdot 2 \\
3 \cdot 6 \\
2 \cdot 2 \\
0\end{array}$ & $\begin{array}{l}0 \\
0 \\
0 \\
0 \\
0 \\
0 \\
0\end{array}$ & $\begin{array}{l}8 \cdot 1 \\
6 \cdot 1 \\
4 \cdot 7 \\
3 \cdot 1 \\
3 \cdot 4 \\
1 \cdot 7 \\
1 \cdot 3\end{array}$ & $\begin{array}{l}0 \cdot 2 \\
0 \\
0 \\
0 \\
0 \\
0 \\
0\end{array}$ & $\begin{array}{l}4 \cdot 9 \\
2 \cdot 5 \\
4 \cdot 8 \\
3 \cdot 7 \\
3 \cdot 3 \\
1 \cdot 0 \\
0\end{array}$ & $\begin{array}{l}5 \cdot 3 \\
4 \cdot 6 \\
2 \cdot 3 \\
0 \\
0 \\
0 \\
0\end{array}$ & $\begin{array}{l}9 \cdot 4 \\
7.3 \\
3.9 \\
1.7 \\
1.5 \\
0.9 \\
0\end{array}$ & $\begin{array}{l}9 \cdot 3 \\
8 \cdot 5 \\
4 \cdot 6 \\
0 \cdot 5 \\
0 \cdot 5 \\
0 \\
0\end{array}$ & $\begin{array}{l}8 \cdot 4 \\
7 \cdot 8 \\
5 \cdot 3 \\
4 \cdot 3 \\
3 \cdot 8 \\
2 \cdot 2 \\
0 \cdot 7\end{array}$ & $\begin{array}{c}13 \cdot 7 \\
10 \cdot 6 \\
5 \cdot 7 \\
0 \cdot 5 \\
0 \cdot 5 \\
0 \\
0\end{array}$ \\
\hline
\end{tabular}

The spermatozoa were obtained from adult Lytechinus pictus which had been kept in isosmotic (I) or hypo-osmotic $(\mathrm{H})$ sea-water for 6 weeks.

* Pooled sperm suspensions from several males were used.

This work was performed under the auspices of the U.S. Atomic Energy Commission. Reference to a company or product name does not imply approval or recommendation of the product by the University of California or the U.S. Atomic Energy Commission to the exclusion of others that may be suitable.

\section{REFERENCES}

Binyon, T. (1966) Salinity tolerance and ionic regulations. In: Physiology of Echinodermata. Ed. R. A. Boolootian. Interscience Publishers, New York.

Bishop, D. W. (1962) Sperm motility. Physiol. Rev. 42, 1.

SALisbury, G. W. (1962) Ionic and osmotic conditions in relation to metabolic control. In: Spermatozoan Motility. Ed. D. W. Bishop. Publication 72, A.A.A.S., Washington, D.C.

Timourian, H. \& Watchmaker, G. (1970) Determinations of spermatozoan motility. Devl Biol. $21,62$.

Tyler, A. \& TYLer, B. S. (1966) The gametes: some properties and procedures. In: Physiology of Echinodermata. Ed. R. A. Boolootian. Interscience Publishers, New York.

Walton, A. (1952) Flow orientation as possible explanation of wave-motion and rheotaxis of spermatozoa. F.exp. Biol. 24, 520 . 